\title{
Erratum: Can China bring its own pipeline to the market?
}

Sabine Louët

Nat. Biotechnol. 22, 1497-1499 (2004)

On page 1497, col.2, paragraph 2, the names of a Shanghai consultancy and its CEO were misspelled. The name of the company is General Biologic and the CEO's name is Matt Chervenak.

\footnotetext{
흥 Erratum: Agbio groups join BIO

Jeffrey L. Fox

Nat. Biotechnol. 22, $1493(2004)$

On page 1493, paragraph 1, line 7, mentions that "The Washington, DC-based Biotechnology Industry Organization (BIO) is gobbling up two agriculture-and-food oriented communication groups — the Council for Biotechnology Information (CBI)... and the Brussels-based Crop Life International (CLI)...." It should have read "The Washington, DC-based Biotechnology Industry Organization (BIO) is gobbling up one agriculture-and-food oriented communication group-the Council for Biotechnology Information (CBI)." Crop Life International remains independent, even though it sometimes receives funding from CBI.
}

\section{Corrigenda: Antisense and siRNA as agonists of Toll-like receptors}

\section{Sudhir Agrawal \& Ekambar R Kandimalla}

Nat. Biotechnol. 22, 1533-1537 (2004)

The title should read, "Role of Toll-like receptors in antisense and siRNA." The last line of paragraph 3, beginning "This article summarizes present evidence...." should be deleted. In Table 1, superscript 'b' in “Sequence c, , should be deleted, and superscript 'a' after 3' in line 3 of that column should be replaced by superscript b. Also in Table 1, in col. 4, line 13, "restinosis" is misspelled; the correct spelling is "restenosis." In Table 2, footnote a, "From reference 27," should read "From reference 44." Reference 1 in the reference list should be deleted and references 2-69 should be renumbered 1-68 to correspond to those in the text. 